\title{
Towards an Intersectional Approach to Patriarchy: Male Homosociality in an American Context
}

\author{
Frank G. Karioris*
}

\begin{abstract}
This article seeks to begin an exploration of the ways that male homosociality can be investigated and talked about using a multidimensional and intersectional lens. In doing this, it puts to the fore an understanding and discussion of patriarchy, while simultaneously situating the discussion amidst current American visions of masculinity. The article aims to provide a further starting point for theorising about men's homosocial relations and the various factors which impact on the nature of these relations and the role that these relations can play in perpetuating or undermining larger social structures which further inequalities. To do this it briefly looks at various elements of these relations, specifically related to power, silence and intimacy.
\end{abstract}

\section{Introduction}

One of the challenges of patriarchy, and systems of power and oppression more generally, is that they are, as Peggy McIntosh put it so succinctly, often invisible to ourselves (McIntosh 1989). Not only are our own privileges often invisible to ourselves, but often so are our relations, interactions, and the role that these play in our individual lives. It was not until I had graduated from college that I started to think not just about my actions in relation to power and oppression, but to think about the ways that my relations with others - and often other men - impacted on me so heavily. What I noticed was the fact that my relations with others were more often than not reflective of a highly individualised and almost crass version of independence. I found I had distanced myself to a great degree from family and friends, and that I had grown accustomed to a life lived without fully committing to my relationships. Having discovered this I began to redress some of the glaring silences that I had created in my life, and to further understand the role that relationships played in the creation of masculinities, a system of oppression and power, and the silences that exist to perpetuate each of these.

Much of the following discussion has stemmed from a personal and academic desire to gain an understanding of men's homosocial relations. Some of the information presented derives from my doctoral thesis which focuses on American men in a university setting and the role that their relations with other men play in their lives. So in that sense the work is both a reflective act, as well as a personal effort at comprehending the role that these relationships play in men's lives, and the way that these relationships traverse and overlap the intersectional identities that we each carry into each of these interactions. This article therefore builds upon personal reflexive practice, as well as a theoretical position which sees men's homosocial relations as spaces where the creation of masculinities occurs, and at the same time as places of fear, power and intimacy. These relations are paradoxical interactions that instil oppressive behaviours - along gender, class, race, and other lines of oppression - as well as relations that can leave individual men struggling as pieces in a system of patriarchy that subjugates each individual and their interactions.

\section{Setting up the discussion}

It is crucial, in understanding and examining the notion of 'patriarchy' and the systemic exchange as it exists in individuals' lives to see and comprehend the varied interlocking and overlapping transpositions of power that are constantly occurring: each, in their own way, 
acting as a contextualising agent to the larger social existence of individual actors. What is meant to be put forward with this is a way of viewing power as fluid, contested and varying while seeing patriarchy as a larger social system that is transformed and perpetuated through individual actions underpinned by the exchange of both various forms of capital and ingrained knowledge. ${ }^{1}$ This suggests that patriarchy can be seen firstly as a broader social system, which is oppressive in specific ways to each person that falls within and under it, while at the same time privileging specific traits or individuals over others. In other words, men, while benefiting as a broad grouping, are at the same time workers in the systemic oppression of both women as well as men. This reading of patriarchy opens up the understanding that the individual is separate from the group and that one must consider both individual and structural elements in coming to see the workings of the system of patriarchy.

This article does not intend to go through each and every element of the workings of patriarchy, but rather would like to suggest for investigation a crucial aspect of the system which, to this point, has often been left neglected or maligned as less worthy of research. This is the relations between men, or what this article terms male homosocial relations. The word 'homosocial', or 'homosociality', stems largely from Jean LipmanBlumen's work in the late seventies and most prominently from Eve Kosofsky-Sedgwick in the mid-eighties (Lipman-Blumen 1976; KosofskySedgwick 1985). ${ }^{2}$ Through a foregrounding of men's homosocial relations, this article investigates the ways that these relations are, in part, shaped themselves, in order to begin to understand the implications these relations can have for the broader social atmosphere. ${ }^{3}$

The article seeks to explicate a number of nuances and expressions of male homosocial relations, seeking from them to present a fractured portrait rather than a simple picture. In this way, it is also crucial to note that the context for this discussion is American men and the specific versions of homosociality which exist in the USA, though much of this may well be applicable to other contexts. It seems helpful at this point to quote Erving Goffman's summation of American masculinity, setting the stage for the way men's relations are constructed and contested.
There is only one complete unblushing male in America: a young, married, white, urban, northern, heterosexual Protestant father of college education, fully employed, of good complexion, weight, and height, and a recent record of sports. Every American male tends to look out upon the world from this perspective... Any male who fails to qualify in any of these ways is likely to view himself - during moments at least - as unworthy, incomplete, and inferior... (Goffman 1963: 128).

In building this description Goffman does not put forward a definition of US masculinity, so much as he is setting out the way that masculinity is one amongst a varied and variegated set of identity formations that intersect and overlap, each one leaving open the possibility of failure - and the subsequent need for silence. The quote also makes plain the fact that the vision of masculinity set out for men is an impossibility, and the competing nature inherent in a form of gendered identity which is rooted in failure. This, though rooted in an American context, can be seen across borders and in various other contexts.

\section{Men's mediated interactions}

There is, inherent in this article, the concept that relations and individuals are of a dialogical character (Taylor 1992: 32-3), which speaks to the fact that each individual works through and with others to create both the relationships and, in a sense, one's self simultaneously. Further, individuals are always in conversation not merely with other individuals, but with the broader social system and field that they are a part of. By seeing the transmission of self and ideology (one might also call this habitus ${ }^{4}$ or performative modalities) working through interactions, it is quintessential to understand these interactions themselves. Then, one can begin to view these mediations between men, as well as through mediating objects and events, as fundamental in the construction of identity for men (Taylor 1992: 35). Mediation here is meant to be understood, following John Guillory, thus: 'if we think of mediation as a process whereby two different realms, persons, objects, or terms are brought into relation, the necessity for mediation implies that these realms, persons, objects, or terms resist a direct relation and perhaps have come into conflict' (Guillory 2010: 342). Or, as Bourdieu puts it '... "interpersonal” relations are 
never, except in appearance, individual-toindividual relationships and that the truth of the interaction is never entirely contained in the interaction' (Bourdieu 1977: 81).

Put another way, these relations are not static or fixed, but are 'endured and supported' (Agamben 2000: 57). Through these statements one gains a sense that interactions or relations are neither simple, unified, nor are they singular. By understanding the mediated nature of relations, whether through objects and events, or through the structured structures laid in place by doxa the unquestioned and unquestionable beliefs which help shape individuals' actions - and habitus, one must then come to recognise the crucial role that these intermediaries play in any given interaction. Thus, at the core of relations, and specifically for this article, men's homosocial relations, is this dialogical and mediated character propelling these relations not merely as external actions upon the self, but as actions which in themselves constitute part of the creation of the self. Therefore, gender (and masculinity) is 'performative in the sense that it constitutes as an effect the very subject it appears to express' (Butler 1991: 24). For Butler, what this means is that one must recognise that individual self-hood is premised upon 'a discourse we never chose but that, paradoxically, initiates and sustains our agency' (Butler 1997: 2). This constituting of the subject also sets up and creates the relations which themselves are acceptable, allowable, and understandable within the specific context and as part of a certain entangled, individuated interaction.

\section{Building on the importance of homosocial} relations, Eve Kosofsky-Sedgwick says that the realms of masculinity and femininity, rather than being binary, are 'orthogonal to each other, "in different, perpendicular dimensions, and therefore... independently variable"" (KosofskySedgwick in Savran 1998: 7). What she is saying is that rather than considering the genders from a standpoint of a binary, one can see them as objects, which, though in conjunction, are nevertheless not reducible to their relation with each other. While this in some way misleadingly shows masculinity and femininity as independent of one another, it gets across an idea about the transmission of gendered habitus between individuals as one highly influenced from members of the same gender. ${ }^{5}$ Michael Flood, continuing this sentiment, states that 'men's practice of gender is a homosocial enactment' (Flood 2003; see also Flood 2008), tying them together.

With this, one can see the importance of homosocial relations to the creation and sustaining of men's relations in general; whereupon ideas about men, masculinity, and homosociality begin to take shape as forms of practice intertwined with each other. In this way then, if homosociality is key to the formation of masculinity, it is therefore conjoined with the workings of patriarchy and inequality. While this is by no means a new revelation, it puts forth a construction of men's relations premised not upon individual actions, but as part of a broader structured habitus that has a strong impact on these relations. Doing this does not negate individual agency but modifies it to include structural calls to inaction, impediments to action, and acknowledging factors outside the individual.

What must be added to this is the intra-gender dynamics at play between various and in some ways competing visions of masculinity. As Raewyn Connell discussed in her seminal book

Masculinities, there is a constant struggle between differing versions of masculinity, which are each seeking to usurp a place at the top of the hierarchy (Connell 2005). Having put forward the notion of 'hegemonic masculinity' - utilising a Gramscian term - Connell and Messerschmidt have subsequently reinvigorated the term through opening up the concept to the multifaceted and multilateral nature of contestations between and within models of masculinity. Hegemonic forms of masculinity provide a model for relations, while connecting 'with the practical constitution of masculinities as ways of living in everyday local circumstances. To the extent they do this, they contribute to hegemony in the society-wide gender order as a whole' (Connell and Messerschmidt 2005: 838). Building on this, and putting forward an intersectional way of viewing masculine relations, they say that one must factor in the institutionalisation of gender inequalities, the role of cultural constructions, and the interplay of gender dynamics with race, class, and region' (ibid.: 839) in any discussion about men's power, privilege or relations.

Through the integration of varied models of masculinity - each situated along different points 
on each axis of identity and privilege - one can further understand the importance these relations take on if we understand them as interactions whereupon forms of knowledge, action, privilege and power are transmitted, conferred or lost.

\section{Silence, power and intimacy}

By viewing men's relations, and therefore men, in this fashion one makes a drastic change in the way their actions and power are seen. Rather than suggesting that men are omnipotent beings who exist outside of the oppressive system, I argue that they too fall under the system as well and are cogs in the wheels of the machine. Men's relations provide them with a space where it is possible to see not just the creation of masculinity, but also fear, power and intimacy. This is not to suggest that these relations are not at the same time tools utilised to gain and exploit privilege, re-instilling oppressive practices along race, class and gender lines. Men's relations are, in this way, paradoxical; being spaces of power and pervasive struggle.

Elaborating on men's social relations, Michael Kimmel in his book Guyland talks about a man who, while having sex with a woman, can think of nothing else except telling his male friends about his sexual exploits. Kimmel relates this exploit all but exclusively to sex, noting that there is a sense of insecurity that underlies it (Kimmel 2008: 206). While he is certainly right that there is an insecurity surrounding sex, what is missing from this interaction is a statement about men's relations with other men and the necessity of silence. Rather than merely seeing this as a claim about women as objects, which it certainly is, one can also see it as a way of finding intimacy and connections between men, both of which they are seeking.

In an interview with an American man, Ben, Kimmel talked about the distinctions between his friendships with men and with women. He said that there was a degree of 'introspection and reflexiveness about my relationships with women which I really crave, and seek out that is not there in my relations with male friends.' Continuing, he said that for him he seeks friendship through discussion, which is mediated through events or actions, whereas for men it is often the event which takes primacy to mediate the relations through. For example, his relationship with his brother is one premised on the typical 'masculine' activities of sports and beer, eschewing conversation in place of action. There is frequently between men a necessary silence, the forced creation of a gap between them. This silence enables men to disown their own need of others while forming a sense of self falsely premised as individuals outside of social systems. In other words, it works to build a picture of the 'self-made man' while disowning an idea of intimacy. The notion of the self-made man also connotes a distancing of class and race, seeking to say that every gain or loss was directly related to the individual themselves (Rotundo 1993: 3).

Through this, one sees a sense of the public, and the power of the public. ${ }^{6}$ Rather than getting closer to an understanding of either themselves or others, the silence of men works to re-intern them and others. It can be seen then as not merely a silence, but in part a distancing from intimacy. By this I mean that the silence created through a distancing of the individual from social structures enshrines a specific variant of intimacy, which is delimited to the private sphere. This does not mean that silence is this, only this, or ever always such, though. Working around silence to find intimacy leads men to claim intimacy in places which frequently perpetuate inequalities or which maligns the notion that there is inequality. Men in their seeking for intimacy must disown intimacy itself and aim to find it through its explicit rejection (Kaplan 2006). Furthermore, 'the modernistic discourse on friendship in Western thought perceives it to be a private bond associated with the emotional' (ibid.: 572). Through the displacement of friendship and intimacy to the realm of the private recasts the public then as necessarily lacking in intimacy and thus as a space of competitiveness.

In sports, it is common to hear a coach telling a player to 'just walk it off' - or the similar phrase 'take it like a man' (Savran 1998). This, for many young men, is the frequent refrain coming at them, not merely from coaches, but from friends, siblings, parents and teachers. It is this sentiment that underlies any number of activities and forms the basis of activities for many young men. For one man whom I interviewed, Marshall, though he never spoke this phrase, it seemed to underpin many of the statements that he was making. In discussing his twenty-first birthday, a major (drinking) event in 
the USA, he said that 'it was supposed to be torturous' and that it seemed his friends were trying to kill him. For him though, this was both a rite of passage and a sign and signifier of his friendship with these other men.

He explicitly states that 'sometimes when you fight with someone it means your relationship is on a really high level.' So, while Marshall sees his friends as confidants, he feels that fighting is not merely part of a relationship, but something which showcases its strength. In this sense, one can see the phrase 'just walk it off' being applied to his friendships as well as the individuals within the relationship. Certain aspects of this mentality can be seen in Loïc Wacquant's descriptions of boxers in the South Side of Chicago, and the connection that their injuries bring to themselves and their relationships with the other men in the club (Wacquant 2004).

Notions of combative masculinity and the selfmade man promulgate an individualised rationalising away of systemic inequality and it is no surprise then that men's homosocial relations are rife with misogynistic attitudes and actions. What one must therefore begin to untangle is the version of masculinity and relations that exists at the margins of this, which are bending the singular vision of these relations and which are breaking down the dominant fiction of an 'unimpaired' and unencumbered masculinity (Silverman 1992: 42). It is in these cracks where one can see the underpinnings of a patriarchal doxa and which allows for insights towards a redressing of inequalities by addressing structural edifices that repurpose men's relations into the service of perpetuating inequality.

\section{Conclusion}

In viewing men's homosocial relations with this lens it allows one to bring to bear both an individual critique while simultaneously maintaining a critical exegesis and understanding of the larger social structures which connect masculinity to power through the system of patriarchy. What this also allows one to do is to further grapple with the politicised and multidimensional aspects of oppression outside of gender, moving an analysis towards essential intersectional aspects such as class, race and sexuality. In making this move, one could also choose to move beyond the term 'patriarchy' to 'kyriarchy'. Coined by Elisabeth Schüssler Fiorenza, kyriarchy refers to a 'sociocultural and religious system of dominations by intersecting multiplicative structures of oppression' which allows for an exploration into the 'interdependence of gender, race, class, and imperial stratifications, as well as into their discursive inscriptions and ideological reproductions'. Further, it 'highlights that people inhabit several structural positions of race, sex, gender, class, and ethnicity' (Fiorenza 2009: 9-10).

This is meant to connect some of the various factors that are interlinked and are necessary in the consideration of masculinity and men's homosocial relations to an understanding of the mechanisms of a patriarchal system. This essay is a brief beginning towards incorporating a theoretical and intersectional approach to understanding men's homosocial relations, and a statement about the importance of these relations to the comprehension of patriarchy. It is a brief but firm statement about the necessity of opening up a critical discourse surrounding this issue within the fields of sociology, social theory, and men and masculinities (Cornwall and Lindisfarne 1994), as well as a further step in politicising masculinities and responses to a wider social system of oppression (Cornwall et al. 2011).

These relations are created by material, structural and phenomenological directives that determine the shape, scope and form of men's interactions and that seek to eliminate alternatives. If we recognise that the system of patriarchy is built on men's oppression of women, at the same time it should lead us to question the dictates which it puts upon men.

It is hoped that this call for further investigation into men's homosocial relations will continue to be answered by a wide array of theorists, scholars and activists who are working with these issues in a variety of contexts. The further investigation of men's homosocial relations will allow for a greater understanding of the social and cultural constraints and causes which both enable and force men into specific relationships with men and women. 


\section{Notes}

* I am grateful to Jerker Edström and Phil Otieno for their invaluable comments and feedback on earlier versions of this article, and to Andrea Cornwall for her many years of support and mentorship. This research has been funded, in part, by a Travel Grant from Central European University.

1 This statement means to give a nod to the important contributions of both Michel Foucault and Pierre Bourdieu, recognising the way that knowledge is powerful in the Foucaultian sense and suggesting that this is itself a form of capital in Bourdieu's neoMarxist sense.

2 This is a small fraction of the burgeoning literature surrounding the concept of 'homosociality', much of which tackles the concept from a literary standpoint. These two sources provide an initial theorising on the notion, setting the groundwork for most other discussions of the topic.

3 The term 'social atmosphere' is attributed, in part, to Leo Linder who uses the term in relation to managing and understanding social media. His use, though, is based on a businessstyle model which is not being utilised here.

4 The concept of habitus is here taken from Pierre Bourdieu, who defines it as: 'The structures constitutive of a particular type of environment (e.g. the material conditions of existence characteristic of a class condition) produce habitus, systems of durable, transposable dispositions, structured

\section{References}

Agamben, G. (2000) 'Notes on Gesture', in Means without End, London: University of Minnesota Press

Bourdieu, P. (1977) Outline of a Theory of Practice, Cambridge: Cambridge University Press

Butler, J. (1997) The Psychic Life of Power: Theories in Subjection, Stanford: Stanford University Press

Butler, J. (1991) 'Imitation and Gender Insubordination', in D. Fuss (ed.), Inside/Out: Lesbian Theories, Gay Theories, London: Routledge Connell, R. (2005) Masculinities, Cambridge: Polity Press

Connell, R.W. and Messerschmidt, J.W. (2005) 'Hegemonic Masculinity: Rethinking the Concept', Gender and Society 19.6: 829-59

Cornwall, A. and Lindisfarne, N. (eds) (1994) Dislocating Masculinities: Comparative Ethnographies, London: Routledge structures predisposed to function as structuring structures, that is, as principles of the generation and structuring of practices and representations which can be objectively "regulated" and "regular" without in any way being the product of obedience to rules...' (Bourdieu 1977: 72).

5 Though one should be careful about being overly determinate about this, as there are many examples of gender socialisation that occur through interactions with members of the opposite gender, and which can and do have a great impact upon the individuals. One can also look towards specific gender training workshops and groups which set out to retrain individuals about this. This trend often stems from a history rooted in consciousnessraising groups.

6 A full discussion of the issue of the public and private sphere and its connection to gender and masculinity is one beyond the scope of this article. For further discussion, see Warner (2002).

7 One could look at various public spaces which men use to share a specific form of intimacy and the ways that these groups and spaces comport and conceive of the interactions within them. Possible groups could be: country clubs, police partners, unions in heavily male sectors, militaries, prisons. While these are just a few examples, each of them showcases a specific form of homosociality connected with varying degrees of intimacy.

Cornwall, A.; Edström, J. and Greig, A. (eds) (2011) Men and Development: Politicizing Masculinities, London: Zed Books

Fiorenza, E.S. (2009) 'Introduction: Exploring the Intersections of Race, Gender, Status, and Ethnicity in Early Christian Studies', in L. Nasrallah and E.S. Fiorenza (eds), Prejudice and Christian Beginnings: Investigating Race, Gender, and Ethnicity in Early Christian Studies, Minneapolis MN: Fortress Press

Flood, M. (2008) 'Men, Sex, and Homosociality: How Bonds between Men Shape their Sexual Relations with Women', Men and Masculinities 10.3: 339-59

Flood, M. (2003) 'Men, Sex and Mateship: How Homosociality Shapes Men's Heterosexual Relations', paper prepared for (Other) Feminisms: An International Women's and 
Gender Studies Conference, University of Queensland, 12-16 July

Goffman, E. (1963) Stigma: Notes on the Management of Spoiled Identities, New York: Simon \& Schuster

Guillory, J. (2010) 'Genesis of the Media

Concept', Critical Inquiry 36: 321-62

Kaplan, D. (2006) 'Public Intimacy: Dynamics of Seduction in Male Homosocial Interactions', Symbolic Interaction 28.4: 571-95

Kimmel, M. (2008) Guyland, London: HarperCollins

Kosofsky-Sedgwick, E. (1985) Between Men: English Literature and Male Homosocial Desire, New York: Columbia University Press

Lipman-Blumen, J. (1976) 'Towards a Homosocial Theory of Sex Roles: An Exploration of the Sex Segregation of Social Institutions', Signs 1.3: 15-31
McIntosh, P. (1989) 'White Privilege: Unpacking the Invisible Knapsack', Peace and Freedom July/August 1989: 9-10

Rotundo, E.A. (1993) American Manhood, New York: Basic Books

Savran, D. (1998) Taking it Like a Man: White Masculinity, Masochism, and Contemporary American Culture, Princeton, NJ: Princeton University Press

Silverman, K. (1992) Male Subjectivity at the Margins, London: Routledge

Taylor, C. (1992) Ethics of Authenticity, Cambridge, MA: Harvard University Press

Wacquant, L. (2004) Body and Soul: Notebooks of an Apprentice Boxer, Oxford: Oxford University Press

Warner, M. (2002) Publics and Counterpublics, New York: Zone Books 